Research Article

\title{
Combined Inositol Hexakisphosphate and Inositol Supplement Consumption Improves Serum Alpha-Amylase Activity and Hematological Parameters in Streptozotocin-Induced Type 2 Diabetic Rats
}

\author{
Shadae R. Foster $\mathbb{D}^{1},{ }^{1}$ Lowell L. Dilworth, ${ }^{2}$ Jean Sparks, ${ }^{3}$ Ruby L. Alexander-Lindo, ${ }^{1}$ \\ and Felix O. Omoruyi $\mathbb{C}^{3}$ \\ ${ }^{1}$ Department of Basic Medical Sciences, Biochemistry Section, UWI, Mona, Jamaica \\ ${ }^{2}$ Department of Pathology, UWI, Mona, Jamaica \\ ${ }^{3}$ Department of Life Sciences, Texas A\&M University, Corpus Christi, USA
}

Correspondence should be addressed to Shadae R. Foster; shadae.foster@mymona.uwi.edu

Received 6 July 2019; Accepted 28 September 2019; Published 15 October 2019

Academic Editor: Masahiro Oike

Copyright (c) 2019 Shadae R. Foster et al. This is an open access article distributed under the Creative Commons Attribution License, which permits unrestricted use, distribution, and reproduction in any medium, provided the original work is properly cited.

\begin{abstract}
This study evaluated the effect of combined inositol hexakisphosphate (IP6) and inositol supplement on organ weight, intestinal ATPase activities, complete blood count, and serum analytes in streptozotocin (STZ)-induced type 2 diabetic rats. High-fat diet and a single intraperitoneal injection of streptozotocin $(35 \mathrm{mg} / \mathrm{kg}$ body weight) were used to induce type 2 diabetes mellitus in Sprague-Dawley rats. The diabetic groups were then treated with either combined IP6 and inositol supplement or glibenclamide for four weeks. Organ weights, intestinal ATPase activities, complete blood count, serum $\alpha$-amylase, total protein, albumin, and globulin content were determined. Pancreatic weight was significantly reduced while relative kidney and liver weights were elevated in the group treated with combined IP6 and inositol supplement compared to the nondiabetic control. Serum $\alpha$-amylase activity for the glibenclamide and combination treated groups was significantly improved compared to that of the untreated diabetic group. Red cell distribution width percentage was significantly lower in the combination treated group compared to that in the untreated diabetic group, while intestinal ATPase activities were unaffected by the treatment regime. Combined IP6 and inositol supplement consumption may protect people with diabetes from increased risk of cardiovascular diseases due to the supplement's ability to maintain red cell distribution width percentage towards the normal control group.
\end{abstract}

\section{Introduction}

Diabetes mellitus is a chronic disorder that occurs either because of the inability of the pancreas to produce adequate amounts of insulin or its failure to utilize available insulin efficiently. Morbidity and mortality among both youth and adult populations have significantly increased due to diabetes mellitus. There is also a strong association between diabetes mellitus and an increased risk of developing cardiovascular diseases, neuropathies, and microvascular damage to organs including the kidneys and eyes. There are several oral hypoglycemic agents commercially available; however, many have undesirable side effects.

Inositol is a naturally occurring cyclitol formerly referred to as a pseudovitamin. Inositol hexakisphosphate (IP6 or InsP6), also known as phytic acid, is a polyphosphorylated inositol derivative. Both IP6 and inositol are abundantly present in many legumes and whole grains and are present in mammalian cells. They are individually involved in the regulation of insulin secretion [1-4]. Abnormalities in inositol metabolism (inosituria and inositol intracellular depletion) have been observed in several human and animal 
studies in association with hyperglycemia and insulin resistance. It was proposed that inositol intratissue depletion could contribute to the progression or development of some diabetes-related microvascular complications [5-9]. According to Croze and Soulage, dietary myo-inositol supplementation could reduce and prevent intracellular depletion of inositol in body tissues [10]. Studies have found that myo-inositol supplementation substantially reduced fat accretion and significantly improved insulin sensitivity and glucose tolerance but did not prevent insulin resistance or obesity development in a diet-induced obese (DIO) mouse model $[10,11]$.

Both IP6 and inositol play vital roles in various cellular processes and are structurally involved in the formation of secondary messengers such as inositol triphosphates (Ins (1, $4,5)$ P3 or IP3) and phosphatidylinositol phosphate lipids (PIP2 or PIP3) in mammalian cells. Consequently, metabolic alteration in their levels could affect a wide range of cellular functions. Shamsuddin et al. demonstrated that when IP6 and inositol are combined in the appropriate ratio, the byproducts are two IP3 signaling molecules, which are essential cellular regulators [12]. We postulate that one of the several mechanisms by which the combination functions is by acting as a precursor for the formation of lower inositol phosphates and phosphatidylinositols. Treatment with combined IP6/inositol can, therefore, result in the increased cellular concentration of inositol triphosphate. Inositol triphosphate is involved in the regulation $\mathrm{Ca}^{2+}$ mobilization and therefore insulin secretion [13, 14]. Previous studies have shown that combined IP6 and inositol possess antidiabetic, anticancer, antioxidant, and organ protective properties and could provide a natural alternative treatment for diabetes mellitus with few or no side effects [15-19]. Hematological and comparative organ weight analyses are widely used to screen drugs and determine toxicity [20]. This study examines the effect of combined IP6 and inositol supplement on organ weights, intestinal ATPase activities, complete blood count, and four serum analytes in streptozotocin-induced type 2 diabetic rats.

\section{Materials and Methods}

2.1. Animal Care. Healthy adult male Sprague-Dawley rats $(168 \pm 5.9 \mathrm{~g})$ were procured from Harlan Laboratories Inc. (Indianapolis, IN, USA). The rats were housed in polypropylene cages with solid floor and bedding materials. The room was maintained at a controlled temperature $\left(22 \pm 2^{\circ} \mathrm{C}\right)$ with humidity $(45 \pm 5 \%)$ and $12 / 12$-hour light/ dark cycle. The animals had free access to standard rat laboratory diet (PicoLab ${ }^{\circledR}$ Rodent Diet $\left.20 ; 5053\right)$ or a highfat diet containing $45 \%$ fat as a percentage of total kcal (D12451; Research Diets Inc., New Brunswick, NJ, USA). They were also provided with clean drinking water ad libitum.

2.2. Ethical Approval. Study approval was obtained after the review of the protocol by the Institutional Animal Care and Use Committee (IACUC) of the Institute of Biosciences and
Technology, Texas A\&M Health Sciences Center, Houston, USA (protocol number 011645).

2.3. Induction of Type 2 Diabetes. Induction of type 2 diabetes was carried out according to a modified version of previously used protocols [21-23]. The rats were fed $45 \%$ high-fat diet for four weeks. At the end of week 2, the rats were administered a single intraperitoneal (i.p.) injection of $35 \mathrm{mg} / \mathrm{kg}$ body weight (b.w.) of streptozotocin (SigmaAldrich, MO, USA) dissolved in $0.1 \mathrm{M}$ of cold citrate buffer ( $\mathrm{pH}$ 4.5). This solution was freshly prepared, shielded from light, and administered within 5 minutes of preparation. Control rats were injected with an equivalent volume of citrate buffer alone. One week later, the nonfasting blood glucose level was measured, and animals with a blood glucose concentration $\geq 300 \mathrm{mg} / \mathrm{dL}$ were considered diabetic. To confirm type 2 diabetes, an antidiabetic drug response test was carried out (previously described) [15]. The rats were classified as having type 2 diabetes mellitus based on a positive response to glibenclamide treatment.

2.4. Experimental Design. The animal trial was an 8-week study. For the first four weeks, six rats were fed a normal basal diet (PicoLab ${ }^{\circledR}$ Rodent Diet 20; 5053) and 24 rats were fed $45 \%$ high-fat diet. Diabetes was induced in 18 of the rats fed with the high-fat diet. At the end of week 4, rats were assigned into the following five groups (six rats per group): nondiabetic control (NC; nondiabetic rats fed basal diets), high-fat control (HFC; high-fat diet and nondiabetic), untreated diabetic control (DC), diabetic rats treated with combined IP6 and inositol supplement (IP6 + INO; $650 \mathrm{mg} /$ $\mathrm{kg}$ body weight/day), and glibenclamide positive control group (Glib; $10 \mathrm{mg} / \mathrm{kg}$ body weight/day). During weeks 4-8, all rats were fed a basal diet along with their respective treatment regime as outlined. The experiment was designed to administer a dosage of 1\% IP6 and inositol combined, which is equivalent to $650 \mathrm{mg} / \mathrm{kg}$ body weight at a ratio of $220: 800$. The IP6 and inositol used were extracted from rice and supplied by Vita-Tech International Inc. (Tustin, CA, USA). Glibenclamide is slightly soluble in water. To improve the solubility and bioavailability of the drug, $1 \%$ sodium carboxymethyl cellulose (Na-CMC) was used as the transport medium. Combined IP6 and inositol were also dissolved in $1 \% \mathrm{Na}-\mathrm{CMC}$. Both were administered by oral gavage once daily. The control groups (NC, HFC, and DC) received $\mathrm{Na}-\mathrm{CMC}$ daily.

2.5. Serum and Complete Blood Count Analyses. The rats were fasted overnight and euthanized by decapitation at the end of eight weeks. Blood samples were collected and stored in the appropriate vacutainer tubes. Serum samples were assessed for the concentrations of total protein, albumin, and $\alpha$-amylase using the Stanbio Sirrus Clinical Chemistry Analyzer. The serum globulin measurements were calculated by subtracting the serum albumin concentrations from the serum total protein concentrations. Complete blood count 
(CBC) analysis was performed on whole blood samples using a Siemens Advia 120 system analyzer.

2.6. Organ Weight. After the collection of the blood samples, the liver, kidneys, intestines, heart, spleen, and pancreas were excised and weighed.

2.7. Intestinal Analysis. The intestine of each rat, which was free of food materials, was excised and sectioned into proximal (duodenum) and distal (jejunum and ileum) portions. Sodium chloride (0.9\%) solution was used to flush the intestinal lumen several times. The scraped mucosa was homogenized and centrifuged (5000 g), and the supernatant was frozen until required for assays [23]. The activities of the ATPases were determined using the methods of Block and Bonting [24] as modified by Bonting et al. [25] and Takeoet al. [26]. ATPase activity was determined by the quantity of inorganic phosphate liberated after incubating with disodium ATP. The protein concentration of the intestinal homogenate was determined using the method of Bradford [27].

2.8. Statistical Analysis. All data were analyzed using the statistical package version 20 software (SPSS Inc, Chicago, Illinois, USA). Variation among test groups was evaluated using the one-way ANOVA. Post hoc analysis was carried out using Duncan's multiple range test to assess the significant difference among the means $(p<0.05)$. The results were expressed as mean \pm S.E.M.

\section{Results}

3.1. Organ Weight. Table 1 shows the weights of the organs at the end of the study. There was no significant difference in mean liver weight ( $p=0.078)$ among the groups. However, the liver weight relative to body weight was significantly increased among the treated and untreated diabetic groups compared to the nondiabetic group. Kidney weight relative to body weight was significantly increased in the treated and untreated diabetic groups compared with the nondiabetic rats $(p<0.05)$. There was a significant reduction in pancreatic weight among the treated and untreated diabetic groups compared with nondiabetic groups. The weights of the spleen and heart among the groups were not significantly different.

3.2. Serum Analytes. Serum $\alpha$-amylase activity was significantly lower in the untreated diabetic group compared to the other groups (Table 2). Serum $\alpha$-amylase activity in diabetic rats treated with combined IP6 and inositol or glibenclamide showed a nonsignificant increase compared to the nondiabetic control group. A significant reduction in serum albumin was observed among the diabetic groups compared to the nondiabetic groups $(p=0.008)$. Serum total protein or globulin levels showed no significant differences among the groups ( $p=0.461$ and $p=0.675$, respectively).
3.3. Complete Blood Count Analysis. The data on complete blood count analysis did not show any significant differences in white blood cell (WBC; $p=0.073$ ), red blood cell (RBC; $p=0.076)$ hemoglobin (HGB; $p=0.106$ ), hematocrit (HCT; $p=0.072)$, mean corpuscular volume (MCV; $p=0.104)$, mean corpuscular hemoglobin ( $\mathrm{MCH} ; p=0.253$ ), hemoglobin distribution width (HDW; $p=0.05$ ), mean corpuscular hemoglobin concentration (MCHC; $p=0.010$ ), cell hemoglobin concentration mean (CHCM; $p=0.115$ ), mean platelet volume (MPV; $p=0.083)$, and platelet count (PLT; $p=0.453$ ) among the groups (Table 3 ). Red cell distribution width (RDW) percentage was significantly elevated in the diabetic control group compared with the nondiabetic control group $(p<0.05)$. Red cell distribution width percentage was maintained in the groups treated with combined IP6 and inositol groups at a level comparable to the nondiabetic control group $(p=0.106)$.

3.4. Intestinal Mucosa ATPases. The activities of proximal and distal intestinal mucosa ATPases were not significantly altered among the groups (Figures 1 and 2).

\section{Discussion}

Type 2 diabetes is characterized by progressive impairment of insulin sensitivity, followed by beta-cell dysfunction. We have reported earlier that the treatment of STZ-induced type 2 diabetic rats with combined IP6 and inositol resulted in significantly reduced food and fluid intake, fasting blood glucose, serum triglycerides, and total cholesterol and improved insulin sensitivity compared to the diabetic control group thus clearly demonstrating that the combination possesses antidiabetic activities [15]. This present study assessed the association between organ weights of type 2 diabetic rats and those treated with combined IP6 and inositol supplement. The observed significant reduction in pancreatic weight in the treated and untreated diabetic groups compared to nondiabetic groups may be due to the destruction of the pancreatic $\beta$-cell resulting from the administration of STZ. Previous studies have shown that morphological changes often occur before changes in organ weight [28]. Comparative organ weight analysis between treated and untreated groups of animals is a sensitive and vital endpoint for evaluating the potentially harmful effects of test compounds in conventional toxicology studies [29]. However, there is controversy surrounding the expression of organ weight data relative to the animal's body weight, even though it has become an acceptable practice. It was reported that absolute organ weights, as opposed to relative weights, should be used [30].

Other studies have reported that there is a strong correlation between liver, kidney, spleen, and heart weights in relation to body weights. However, either absolute organ weight or other alternative analysis methods should be utilized when evaluating drug toxicity of other organs such as the pituitary gland, ovaries, thymus, and thyroid-parathyroid [31]. Our data showed no significant differences in 
TABLE 1: Organ weights of diabetic rats treated with combined IP6 and inositol supplement or glibenclamide.

\begin{tabular}{|c|c|c|c|c|c|}
\hline Mean weights & NC & $\mathrm{HFC}$ & DC & IP6 + INO & Glib \\
\hline Liver $(\mathrm{g})$ & $10.7 \pm 0.31^{\mathrm{a}}$ & $10.2 \pm 0.35^{\mathrm{a}}$ & $11.1 \pm 0.45^{\mathrm{a}}$ & $11.0 \pm 0.37^{\mathrm{a}}$ & $11.2 \pm .19^{\mathrm{a}}$ \\
\hline Relative liver wt. (\%) & $3.02 \pm 0.56^{\mathrm{a}}$ & $2.78 \pm 0.07^{\mathrm{a}}$ & $3.78 \pm 0.13^{\mathrm{b}}$ & $3.61 \pm 0.14^{\mathrm{b}}$ & $3.38 \pm 0.13^{\mathrm{b}}$ \\
\hline Kidney (g) & $1.18 \pm 0.02^{\mathrm{a}}$ & $1.2 \pm 0.07^{\mathrm{a}}$ & $1.52 \pm 0.09^{\mathrm{b}}$ & $1.45 \pm 0.06^{\mathrm{b}}$ & $1.44 \pm 0.04^{\mathrm{b}}$ \\
\hline Relative kidney wt. (\%) & $0.33 \pm 0.01^{\mathrm{a}}$ & $0.33 \pm 0.01^{\mathrm{a}}$ & $0.51 \pm 0.03^{\mathrm{b}}$ & $0.47 \pm 0.03^{\mathrm{b}}$ & $0.44 \pm 0.03^{\mathrm{b}}$ \\
\hline Spleen $(\mathrm{g})$ & $0.67 \pm 0.03^{\mathrm{a}}$ & $0.69 \pm 0.06^{\mathrm{a}}$ & $0.63 \pm 0.05^{\mathrm{a}}$ & $0.60 \pm 0.03^{\mathrm{a}}$ & $0.60 \pm 0.03^{\mathrm{a}}$ \\
\hline Heart $(\mathrm{g})$ & $1.36 \pm 0.06^{\mathrm{a}}$ & $1.32 \pm 0.05^{\mathrm{a}}$ & $1.30 \pm 0.05^{\mathrm{a}}$ & $1.35 \pm 0.51^{\mathrm{a}}$ & $1.31 \pm 0.47^{\mathrm{a}}$ \\
\hline Pancreas (g) & $1.33 \pm 0.1^{\mathrm{a}}$ & $1.56 \pm 0.1^{\mathrm{a}}$ & $0.93 \pm 0.09^{\mathrm{b}}$ & $0.97 \pm 0.07^{\mathrm{b}}$ & $0.84 \pm 0.06^{\mathrm{b}}$ \\
\hline
\end{tabular}

Note. Data are shown as mean \pm S.E.M. The mean values in a row with different superscript letters are significantly different at $p<0.05$, as assessed by Duncan's multiple range test. Relative organ wt. $\%=($ organ weight $(\mathrm{g}) /$ body wt $(\mathrm{g})) \times 100$. NC, normal control; HFC, high-fat control; DC, diabetic untreated control; IP6 + INO, combined IP6 and inositol.

TABle 2: Serum $\alpha$-amylase, total protein, albumin, and globulin concentration in diabetic rats treated with combined IP6 and inositol supplement or glibenclamide.

\begin{tabular}{|c|c|c|c|c|c|}
\hline Parameters & $\mathrm{NC}$ & HFC & $\mathrm{DC}$ & IP6 + INO & Glib \\
\hline$\alpha$-Amylase activity (U/L) & $1599 \pm 21^{\mathrm{bc}}$ & $1544 \pm 57^{\mathrm{ab}}$ & $1457 \pm 31^{\mathrm{a}}$ & $1689 \pm 19^{c}$ & $1655 \pm 38^{\mathrm{bc}}$ \\
\hline Total protein $(\mathrm{g} / \mathrm{dL})$ & $7.9 \pm 0.16^{\mathrm{a}}$ & $8.4 \pm 0.19^{\mathrm{a}}$ & $7.8 \pm 0.23^{\mathrm{a}}$ & $7.9 \pm 0.26^{\mathrm{a}}$ & $8 \pm 0.26^{\mathrm{a}}$ \\
\hline Albumin $(\mathrm{g} / \mathrm{dL})$ & $5.13 \pm 0.14^{\mathrm{a}}$ & $4.81 \pm 0.16^{\mathrm{a}}$ & $4.38 \pm 0.09^{\mathrm{b}}$ & $4.5 \pm 0.17^{\mathrm{b}}$ & $4.45 \pm 0.12^{\mathrm{b}}$ \\
\hline Globulin (g/dL) & $3.1 \pm 0.41^{\mathrm{a}}$ & $3.5 \pm 0.31^{\mathrm{a}}$ & $3.38 \pm 0.29^{\mathrm{a}}$ & $3.28 \pm 0.24^{\mathrm{a}}$ & $3.58 \pm 0.26^{\mathrm{a}}$ \\
\hline
\end{tabular}

Note. Data are shown as mean \pm S.E.M $(n=6)$. The mean values in a row with different superscript letters are significantly different at $p<0.05$, as assessed by Duncan's multiple range test. NC, normal control; HFC, high-fat control; DC, diabetic untreated control; IP6 + INO, combined IP6 and inositol.

TABLE 3: Complete blood count analysis of diabetic rats treated with combined IP6 and inositol supplement or glibenclamide.

\begin{tabular}{|c|c|c|c|c|c|}
\hline Hematology & $\mathrm{NC}$ & $\mathrm{HFC}$ & $\mathrm{DC}$ & IP6 + INO & Glib \\
\hline WBC $\left(10^{3} / \mathrm{uL}\right)$ & $12.9 \pm 0.24^{\mathrm{a}}$ & $13.42 \pm 1.7^{\mathrm{a}}$ & $9.61 \pm 1.27^{\mathrm{a}}$ & $10.3 \pm 0.64^{\mathrm{a}}$ & $9.7 \pm 1.45^{\mathrm{a}}$ \\
\hline $\mathrm{RBC}\left(10^{6} / \mathrm{uL}\right)$ & $9.45 \pm 0.2^{\mathrm{a}}$ & $9.37 \pm 0.3^{\mathrm{a}}$ & $8.95 \pm 0.20^{\mathrm{a}}$ & $9.71 \pm 0.13^{\mathrm{a}}$ & $9.38 \pm 0.2^{\mathrm{a}}$ \\
\hline Hemoglobin $(\mathrm{g} / \mathrm{dL})$ & $17.23 \pm 0.3^{\mathrm{a}}$ & $17.23 \pm 0.4^{\mathrm{a}}$ & $16.6 \pm 0.2^{\mathrm{a}}$ & $17.62 \pm 0.3^{\mathrm{a}}$ & $17.1 \pm 0.47^{\mathrm{a}}$ \\
\hline Hematocrit (\%) & $51.13 \pm 0.3^{\mathrm{a}}$ & $51.15 \pm 1.6^{\mathrm{a}}$ & $49.8 \pm 0.6^{\mathrm{a}}$ & $53.32 \pm 0.6^{\mathrm{a}}$ & $51.8 \pm 1.52^{\mathrm{a}}$ \\
\hline $\operatorname{MCV}(\mathrm{fL})$ & $54.1 \pm 0.64^{\mathrm{a}}$ & $54.68 \pm 1.0^{\mathrm{a}}$ & $55.8 \pm 0.63^{\mathrm{a}}$ & $54.9 \pm 0.23^{\mathrm{a}}$ & $55.3 \pm 0.44^{\mathrm{a}}$ \\
\hline $\mathrm{MCH}(\mathrm{pg})$ & $18.27 \pm 0.1^{\mathrm{a}}$ & $18.4 \pm 0.42^{\mathrm{a}}$ & $18.6 \pm 0.29^{\mathrm{a}}$ & $18.16 \pm 0.2^{\mathrm{a}}$ & $18.2 \pm 0.11^{\mathrm{a}}$ \\
\hline $\mathrm{MCHC}(\mathrm{g} / \mathrm{dL})$ & $33.73 \pm 0.1^{\mathrm{a}}$ & $33.6 \pm 0.34^{\mathrm{a}}$ & $33.4 \pm 0.18^{\mathrm{a}}$ & $33.06 \pm 0.3^{\mathrm{a}}$ & $33.1 \pm 0.23^{\mathrm{a}}$ \\
\hline $\mathrm{CHCM}(\mathrm{g} / \mathrm{dL})$ & $33.6 \pm 0.9^{\mathrm{a}}$ & $33.6 \pm 0.4^{\mathrm{a}}$ & $33.4 \pm 0.3^{\mathrm{a}}$ & $32.8 \pm 0.3^{\mathrm{a}}$ & $32.8 \pm 0.25^{\mathrm{a}}$ \\
\hline RDW (\%) & $11.9 \pm 0.15^{\mathrm{a}}$ & $12 \pm 0.91^{\mathrm{a}}$ & $12.9 \pm 0.14^{\mathrm{b}}$ & $12.4 \pm 0.17^{\mathrm{a}}$ & $12.3 \pm 0.21^{\mathrm{a}}$ \\
\hline HDW (g/dL) & $2.8 \pm 0.02^{\mathrm{a}}$ & $2.8 \pm 0.03^{\mathrm{a}}$ & $2.7 \pm 0.06^{\mathrm{a}}$ & $2.7 \pm 0.05^{\mathrm{a}}$ & $2.61 \pm 0.05^{\mathrm{a}}$ \\
\hline $\operatorname{PLT}\left(10^{3} / \mathrm{uL}\right)$ & $582 \pm 143^{\mathrm{a}}$ & $673 \pm 116^{\mathrm{a}}$ & $637 \pm 59.5^{\mathrm{a}}$ & $681 \pm 42.2^{\mathrm{a}}$ & $685 \pm 83.2^{\mathrm{a}}$ \\
\hline MPV (fL) & $6.7 \pm 0.09^{\mathrm{a}}$ & $6.4 \pm 0.15^{\mathrm{a}}$ & $6.7 \pm 0.15^{\mathrm{a}}$ & $6.9 \pm 0.17^{\mathrm{a}}$ & $6.7 \pm 0.17^{\mathrm{a}}$ \\
\hline
\end{tabular}

Note. Data are shown as mean \pm S.E.M $(n=6)$. The mean values in a row with different superscript letters are significantly different at $p<0.05$, as assessed by Duncan's multiple range test. NC, normal control; HFC, high-fat control; DC, diabetic untreated control; IP6 + INO, combined IP6 and inositol; RDW, red cell distribution of width, HDW, hemoglobin distribution width; WBC, white blood cell; RBC, red blood cell; HGB, hemoglobin; HCT, haematocrit; MCV, mean corpuscular volume; $\mathrm{MCH}$, mean corpuscular hemoglobin; $\mathrm{MCHC}$, mean corpuscular hemoglobin concentration; CHCM, cell hemoglobin concentration mean; MPV, mean platelet volume; PLT, platelet count.

the weights of the liver, spleen, and heart among the groups. However, there was a significant increase in relative weights of the liver or kidney in the treated and untreated diabetic groups compared to the normal control group, which may be indicative of liver or kidney hypertrophy. These results are not in agreement with liver morphology, absolute liver weight, and serum markers of liver damage [17]. Serum markers of kidney damage, creatinine, uric acid, and urea nitrogen concentrations indicated that treatment of diabetic rats with combined IP6 and inositol supplement caused no adverse effect on kidney integrity [17]. The serum biochemical markers did not agree with absolute and relative kidney weight which could suggest that relative and absolute kidney weight results are either misleading or significant changes in kidney weight occurred before serum biochemical changes.

The digestive enzyme amylase is synthesized and secreted by the pancreatic exocrine system and salivary glands and is responsible for the metabolic degradation of starch and glycogen to maltose and oligosaccharides. Serum $\alpha$-amylase concentration was significantly lower in the untreated diabetic group compared to the other groups. Reduction in serum $\alpha$-amylase activity observed in diabetic individuals may be due to insulin insufficiency since insulin acts as a secretagogue of amylase when carbohydrate ingestion increases $[32,33]$. Previous studies have suggested that low serum $\alpha$-amylase concentration may be due to metabolic abnormalities associated with diminished 


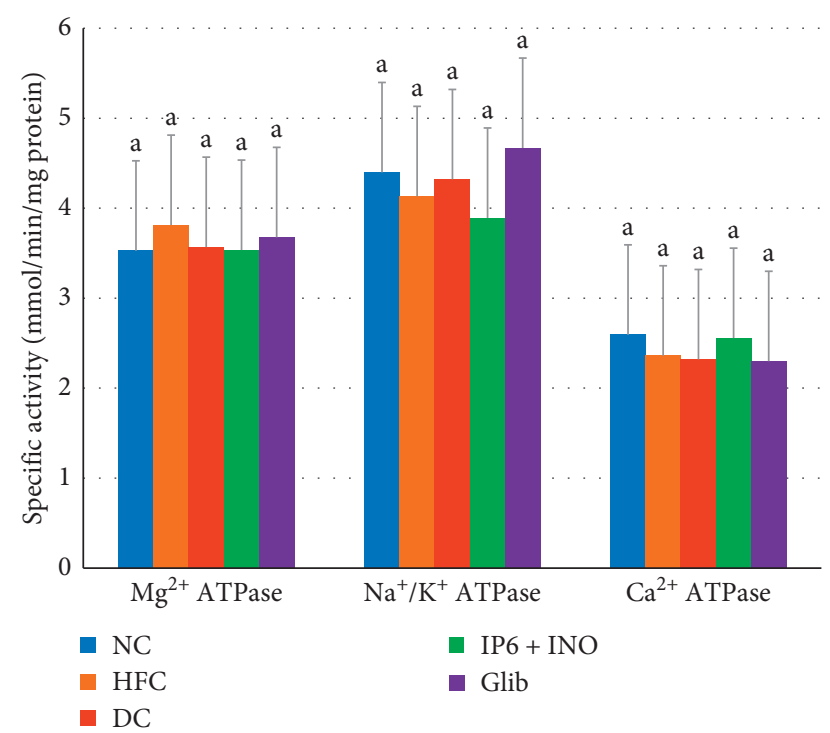

Figure 1: Proximal intestinal ATPase activity among diabetic rats treated with combined IP6 and inositol supplement or glibenclamide. Data are shown as mean \pm S.E.M $(n=6)$. The mean values in a column with different superscript letters are significantly different at $p<0.05$, as assessed by Duncan's multiple range test.

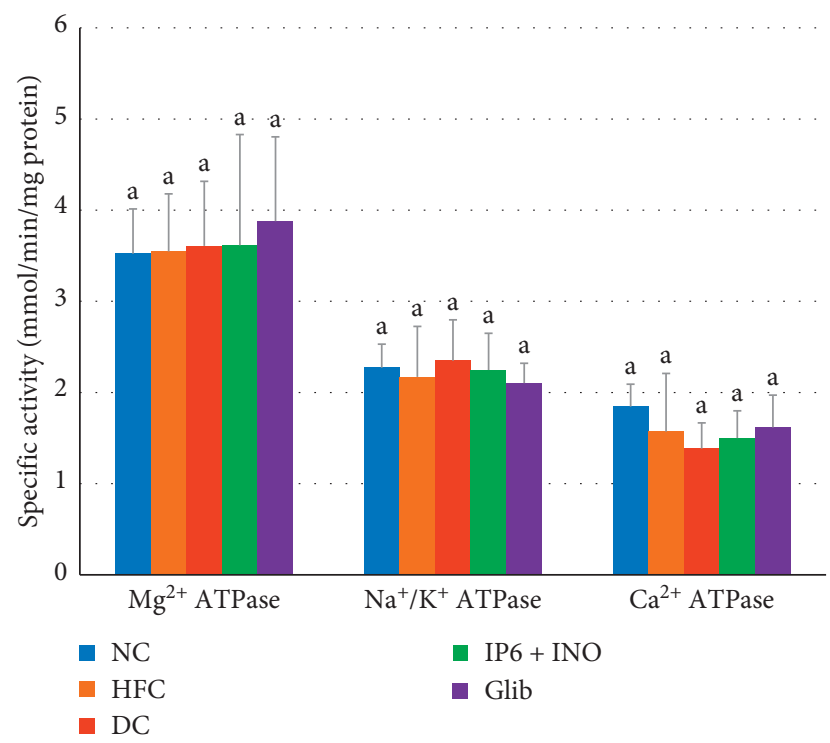

FIgUre 2: Distal intestinal ATPase activity among diabetic rats treated with combined IP6 and inositol supplement or glibenclamide. Data are shown as mean \pm S.E.M $(n=6)$. The mean values in a column with different superscript letters are significantly different at $p<0.05$, as assessed by Duncan's multiple range test.

pancreatic exocrine-endocrine relationship [34, 35]. The observed nonsignificant increase in serum $\alpha$-amylase activity in diabetic rats treated with combined IP6 and inositol or glibenclamide compared to the nondiabetic control group suggest that treatment with the supplement or glibenclamide may restore the metabolic abnormalities associated with an endocrine-exocrine function in diabetes. The observed increasing trend in serum $\alpha$-amylase activity in the treated groups may account for our earlier reported significant reduction in insulin resistance [15].

Albumin, the most abundant serum protein, is a globular protein synthesized exclusively by the liver. Serum albumin levels tend to decrease as chronic liver diseases progress. The two main functions of albumin are the maintenance of plasma oncotic pressure and facilitation of the transport of different metabolites in blood. Protein glycation is the nonenzymatic protein modification that occurs when glucose covalently binds to the protein molecule. Glycation is promoted by elevated blood glucose, as seen in diabetic individuals. Spontaneous modification of the protein molecule will result in the formation of heterogeneous fluorescent molecules called advanced glycation end products (AGEs). The gradual accumulation of AGEs in the blood vessel can lead to many pathological complications in diabetic individuals. One such complication is lipid peroxidation through the generation of free radicals [36]. Low serum albumin is usually associated with cardiovascular risk factors and accelerated atherosclerosis [37]. In this study, treatment with the supplement or glibenclamide did not significantly alter serum total protein, albumin, and globulin levels compared to the untreated diabetic group. A decrease in serum albumin levels in diabetic individuals may not be useful as an early marker for cardiovascular disease development. The prolonged effect of IP6 and inositol combination supplementation on serum protein needs to be further investigated.

Red blood cell (RBCs) count is an important marker in the identification of diabetic patients who are at risk of developing microvascular complications [38]. Red cell distribution width (RDW) is a numerical measure of the amount of variability in the RBC size (e.g., anisocytosis) and is routinely used in the differential diagnosis of anemia [39]. Studies have shown that there is an association between high levels of RDW and the risk of developing cardiovascular disease and nephropathy $[40,41]$. The impairment of erythropoiesis has been shown to be related to an increase in RDW which may be due to chronic inflammation and oxidative stress. Inflammation and oxidative stress are cornerstones in the development of type 2 diabetes [42], and they contribute to the development of diabetic complications. Studies have suggested RDW can be used as a predictor of cardiovascular diseases and anemia [43-45]. Weiss and Goodnough reported that inflammation may increase RDW levels by impairing iron metabolism and inhibiting the production or reducing red blood cell survival [46]. On the other hand, Agarwal suggested that oxidative stress may reduce erythrocyte survival through an increase of circulating premature erythrocytes [47]. It was proposed that RDW may be an important clinical marker of vascular complications in individuals with diabetes mellitus. Cakir et al. reported significant increases in RDW values in type 2 diabetic patients [48]. It was proposed that the ideal treatment for diabetes would be a medication that can lower blood glucose as well as reduce oxidation status and diabetic complications [38]. In this study, the RDW values were significantly higher in untreated diabetic rats compared to the other groups. However, red cell distribution width 
percentage was comparable to the normal control in all the other groups, suggesting that the untreated diabetic control may be at risk of developing vascular diseases. This is plausible, as dyslipidemia which is an established risk factor of cardiovascular diseases was observed in the untreated diabetic group test animals [17]. The observed reduction in RDW levels in the diabetic rats treated with the combination or glibenclamide is indicative of some level of protection against the development of vascular diseases.

Adenosine triphosphatases $\left(\mathrm{Mg}^{2+}, \mathrm{Na}^{+} / \mathrm{K}^{+}\right.$and $\mathrm{Ca}^{2+}$ ATPase) have been primarily implicated in the active transport of minerals across the mucosal membrane and energy production. The activities of intestinal mucosa ATPases were not significantly altered among the groups. The observed decreasing trend in the $\mathrm{Na}^{+} / \mathrm{K}^{+}$ATPase activity in the group treated with combined IP6 and inositol supplement may partly account for its hypoglycemic activity. Studies have shown that reduced ATPase activity may lead to reduced blood glucose concentrations. Dilworth et al. reported that reduction in the absorption of digested materials in rats fed phytic acid extracted from sweet potato might be due to the reduction in intestinal mucosa $\mathrm{Na}^{+} / \mathrm{K}^{+}$ATPase activity with a subsequent decrease in blood glucose concentrations [49].

\section{Conclusion}

This study demonstrates that combined IP6 and inositol may protect subjects with type 2 diabetes from increased risk of cardiovascular diseases due to its ability to maintain red cell distribution width percentage within the normal range. The combination may also restore the metabolic abnormalities associated with an endocrine-exocrine function in diabetes mellitus.

\section{Data Availability}

The data used to support the findings of this study are available from the corresponding author upon request.

\section{Conflicts of Interest}

The authors report no conflicts of interest.

\section{Acknowledgments}

This work was supported by the Office of Graduate Studies and Research Grant and the Principal's New Initiative Grant of the University of the West Indies, Mona Campus.

\section{References}

[1] I. Vucenik and A. M. Shamsuddin, "Cancer inhibition by inositol hexaphosphate (IP6) and inositol: from laboratory to clinic," The Journal of Nutrition, vol. 133, no. 11, pp. 3778S3784S, 2003.

[2] C. J. Barker, I. B. Leibiger, B. Leibiger, and P.-O. Berggren, "Phosphorylated inositol compounds in $\beta$-cell stimulus-response coupling," American Journal of Physiology-Endocrinology and Metabolism, vol. 283, no. 6, pp. E1113-E1122, 2002.
[3] C. J. Barker, C. Illies, R. Fiume, G. C. Gaboardi, J. Yu, and P.-O. Berggren, "Diphosphoinositol pentakisphosphate as a novel mediator of insulin exocytosis," Advances in Enzyme Regulation, vol. 49, no. 1, pp. 168-173, 2009.

[4] P.-O. Berggren and C. J. Barker, "A key role for phosphorylated inositol compounds in pancreatic $\beta$-cell stimulus-secretion coupling," Advances in Enzyme Regulation, vol. 48, no. 1, pp. 276-294, 2008.

[5] H.-H. Chang, H.-N. Chao, C. S. Walker, S.-Y. Choong, A. Phillips, and K. M. Loomes, "Renal depletion of myoinositol is associated with its increased degradation in animal models of metabolic disease," American Journal of PhysiologyRenal Physiology, vol. 309, no. 9, pp. F755-F763, 2015.

[6] H.-H. Chang, B. Choong, A. R. Phillips, and K. M. Loomes, "The diabetic rat kidney mediates inosituria and selective urinary partitioning of D-chiro-inositol," Experimental Biology and Medicine, vol. 240, no. 1, pp. 8-14, 2015.

[7] M. L. Croze and C. O. Soulage, "Potential role and therapeutic interests of myo-inositol in metabolic diseases," Biochimie, vol. 95, no. 10, pp. 1811-1827, 2013.

[8] A. S. Kennington, C. R. Hill, J. Craig et al., "Low urinarychiroinositol excretion in non-insulin-dependent diabetes mellitus," New England Journal of Medicine, vol. 323, no. 6, pp. 373-378, 1990.

[9] T.-H. Sun, D. B. Heimark, T. Nguygen, J. L. Nadler, and J. Larner, "Both myo-inositol to chiro-inositol epimerase activities and chiro-inositol to myo-inositol ratios are decreased in tissues of GK type 2 diabetic rats compared to Wistar controls," Biochemical and Biophysical Research Communications, vol. 293, no. 3, pp. 1092-1098, 2002.

[10] M. L. Croze, A. Géloën, and C. O. Soulage, "Abnormalities in myo-inositol metabolism associated with type 2 diabetes in mice fed a high-fat diet: benefits of a dietary myo-inositol supplementation," British Journal of Nutrition, vol. 113, no. 12, pp. 1862-1875, 2015.

[11] M. L. Croze, R. E. Vella, N. J. Pillon et al., "Chronic treatment with myo-inositol reduces white adipose tissue accretion and improves insulin sensitivity in female mice," The Journal of Nutritional Biochemistry, vol. 24, no. 2, pp. 457-466, 2013.

[12] A. M. Shamsuddin, A. Ullah, and A. K. Chakravarthy, "Inositol and inositol hexaphosphate suppress cell proliferation and tumor formation in CD-1 mice," Carcinogenesis, vol. 10, no. 8, pp. 1461-1463, 1989.

[13] R. F. Irvine, "Inositide evolution - towards turtle domination?," The Journal of Physiology, vol. 566, no. 2, pp. 295-300, 2005.

[14] R. F. Irvine and M. J. Schell, "Back in the water: the return of the inositol phosphates," Nature Reviews Molecular Cell Biology, vol. 2, no. 5, pp. 327-338, 2001.

[15] S. R. Foster, F. O. Omoruyi, J. Bustamante, R. L. A. Lindo, and L. L. Dilworth, "The effect of combined inositol hexakisphosphate and inositol supplement in streptozotocin-induced type 2 diabetic rats," International Journal of Experimental Pathology, vol. 97, no. 5, pp. 397-407, 2016.

[16] S. R. Foster, L. L. Dilworth, R. K. Thompson, R. L. AlexanderLindo, and F. O. Omoruyi, "Effects of combined inositol hexakisphosphate and inositol supplement on antioxidant activity and metabolic enzymes in the liver of streptozotocininduced type 2 diabetic rats," Chemico-Biological Interactions, vol. 275, pp. 108-115, 2017.

[17] S. R. Foster, L. L. Dilworth, F. O. Omoruyi, R. Thompson, and R. L. Alexander-Lindo, "Pancreatic and renal function in streptozotocin-induced type 2 diabetic rats administered combined inositol hexakisphosphate and inositol supplement," Biomedicine \& Pharmacotherapy, vol. 96, pp. 72-77, 2017. 
[18] A. M. Shamsuddin, I. Vucenik, and K. E. Cole, "IP6: a novel anti-cancer agent," Life Sciences, vol. 61, no. 4, pp. 343-354, 1997.

[19] L. W. Wattenberg, "Chemoprevention of pulmonary carcinogenesis by myo-inositol," Anticancer Research, vol. 19, no. 5A, pp. 3659-3661, 1999.

[20] R. S. Suja, A. M. Nair, S. Sujith, J. Preethy, and A. K. Deepa, "Evaluation of immunomodulatory potential of Emblica officinalis fruit pulp extract in mice," Indian Journal of Animal Research, vol. 43, no. 2, pp. 103-106, 2009.

[21] R. S. Danda, N. M. Habiba, H. Rincon-Choles et al., "Kidney involvement in a nongenetic rat model of type 2 diabetes," Kidney International, vol. 68, no. 6, pp. 2562-2571, 2005.

[22] K. Srinivasan, B. Viswanad, L. Asrat, C. L. Kaul, and P. Ramarao, "Combination of high-fat diet-fed and low-dose streptozotocin-treated rat: a model for type 2 diabetes and pharmacological screening," Pharmacological Research, vol. 52, no. 4, pp. 313-320, 2005.

[23] S. S. Percival and B. O. Schneeman, "Long term pancreatic response to feeding heat damaged casein in rats," The Journal of Nutrition, vol. 109, no. 9, pp. 1609-1614, 1979.

[24] J. B. Block and S. L. Bonting, "Sodium-Potassium activated adenosinetriphosphatase and cation transport in normal and leukemic human leukocytes," Enzymologia biologica et clinica, vol. 4, no. 4, pp. 183-198, 1964.

[25] S. L. Bonting, L. L. Caravaggio, and N. M. Hawkins, "Studies on sodium-potassium-activated adenosinetriphosphatase. VI. Its role in cation transport in the lens of cat, calf and rabbit," Archives of Biochemistry and Biophysics, vol. 101, no. 1, pp. 47-55, 1963.

[26] S. Takeo, L. Fliegel, R. E. Beamish, and N. S. Dhalla, "Effects of adrenochrome on rat heart sarcolemmal ATPase activities," Biochemical Pharmacology, vol. 29, no. 4, pp. 559-564, 1980.

[27] M. M. Bradford, "A rapid and sensitive method for the quantitation of microgram quantities of protein utilizing the principle of protein-dye binding," Analytical Biochemistry, vol. 72, no. 1-2, pp. 248-254, 1976.

[28] Y. Piao, Y. Liu, and X. Xie, "Change trends of organ weight background data in sprague dawley rats at different ages," Journal of Toxicologic Pathology, vol. 26, no. 1, pp. 29-34, 2013.

[29] S. A. Bailey, R. H. Zidell, and R. W. Perry, "Relationships between organ weight and body/brain weight in the rat: what is the best analytical endpoint?," Toxicologic Pathology, vol. 32, no. 4, pp. 448-466, 2004.

[30] M. T. Stevens, "The value of relative organ weights," Toxicology, vol. 5, no. 3, pp. 311-318, 1976.

[31] R. Nirogi, V. K. Goyal, S. Jana, S. K. Pandey, and A. Gothi, "What suits best for organ weight analysis: review of relationship between organ weight and body/brain weight for rodent toxicity studies," Journal of Pharmaceutical Sciences and Research, vol. 5, no. 4, p. 1525, 2014.

[32] A. A. Aughsteen, M. S. Abu-Umair, and S. A. Mahmoud, "Biochemical analysis of serum pancreatic amylase and lipase enzymes in patients with type 1 and type 2 diabetes mellitus," Saudi Medical Journal, vol. 26, no. 7, pp. 73-77, 2005.

[33] S. G. Barreto, C. J. Carati, J. Toouli, and G. T. P. Saccone, "The islet-acinar axis of the pancreas: more than just insulin," American Journal of Physiology-Gastrointestinal and Liver Physiology, vol. 299, no. 1, pp. G10-G22, 2010.

[34] R. Yadav, J. P. Bhartiya, S. K. Verma, and M. K. Nandkeoliar, "The evaluation of serum amylase in the patients of type 2 diabetes mellitus, with a possible correlation with the pancreatic functions," Journal of Clinical and Diagnostic Research, vol. 7, pp. 1291-4, 2013.
[35] K. Nakajima, T. Nemoto, T. Muneyuki, M. Kakei, H. Fuchigami, and H. Munakata, "Low serum amylase in association with metabolic syndrome and diabetes: a community-based study," Cardiovascular Diabetology, vol. 10, no. 1, p. 34, 2011.

[36] G. Stark, "Functional consequences of oxidative membrane damage," Journal of Membrane Biology, vol. 205, no. 1, pp. 1-16, 2005.

[37] A. R. Folsom, J. Ma, J. H. Eckfeldt et al., "Low serum albumin: association with diabetes mellitus and other cardiovascular risk factors but not with prevalent cardiovascular disease or carotid artery intima-media thickness," Annals of Epidemiology, vol. 5, no. 3, pp. 186-191, 1995.

[38] A. Abdel-Moneim, E. S. Abdel-Reheim, M. Semmler, W. Addaleel et al., "The impact of glycemic status and metformin administration on red blood cell indices and oxidative stress in type 2 diabetic patients," Malaysian Journal of Medical Sciences, vol. 26, no. 4, pp. 47-60, 2019.

[39] T. C. Evans and D. Jehle, "The red blood cell distribution width," The Journal of Emergency Medicine, vol. 9, pp. 71-74, 1991.

[40] M. Tonelli, F. Sacks, M. Arnold, L. Moye, B. Davis, and M. Pfeffer, "Relation between red blood cell distribution width and cardiovascular event rate in people with coronary disease," Circulation, vol. 117, no. 2, pp. 163-168, 2008.

[41] N. Malandrino, W. C. Wu, T. H. Taveira, H. B. Whitlatch, and R. J. Smith, "Association between red blood cell distribution width and macrovascular and microvascular complications in diabetes," Diabetologia, vol. 55, no. 1, pp. 226-235, 2012.

[42] H. Atalay, B. Boyuk, M. Ates, S. Guzel, A. Celebi, and I. Ekizoglu, "Red cell distribution width and acute complications of diabetes," Acta Endocrinologica (Bucharest), vol. 14, no. 4, pp. 514-519, 2018.

[43] M. Saygin, O. Ozturk, M. F. Ozguner, A. Akkaya, and E. Varol, "Hematological parameters as predictors of cardiovascular disease in obstructive sleep apnea syndrome patients," Angiology, vol. 67, no. 5, pp. 461-470, 2016.

[44] Y. Uemura, R. Shibata, K. Takemoto et al., "Elevation of red blood cell distribution width during hospitalization predicts mortality in patients with acute decompensated heart failure," Journal of Cardiology, vol. 67, no. 3, pp. 268-273, 2016.

[45] H. E. Yoon, S. J. Kim, H. S. Hwang, S. Chung, C. W. Yang, and S. J. Shin, "Progressive rise in red blood cell distribution width predicts mortality and cardiovascular events in end-stage renal disease patients," PLoS One, vol. 10, no. 5, Article ID e0126272, 2015.

[46] G. Weiss and L. T. Goodnough, "Anemia of chronic disease," New England Journal of Medicine, vol. 352, no. 10, pp. 1011-1023, 2005.

[47] S. Agarwal, "Red cell distribution width, inflammatory markers and cardiorespiratory fitness: results from the $\mathrm{Na}-$ tional Health and Nutrition Examination Survey," Indian Heart Journal, vol. 64, no. 4, pp. 380-387, 2012.

[48] L. Cakir, G. Aktas, O. Enginyurt, and S. A. Cakir, "Mean platelet volume increases in type 2 diabetes mellitus independent of HbA1c level," Acta Medica Mediterranea, vol. 30, no. 2, pp. 425-428, 2014.

[49] L. L. Dilworth, F. O. Omoruyi, O. R. Simon, E. S. Morrison, and H. N. Asemota, "The effect of phytic acid on the levels of blood glucose and some enzymes of carbohydrate and lipid metabolism," West Indian Medical Journal, vol. 54, pp. 102106, 2005. 

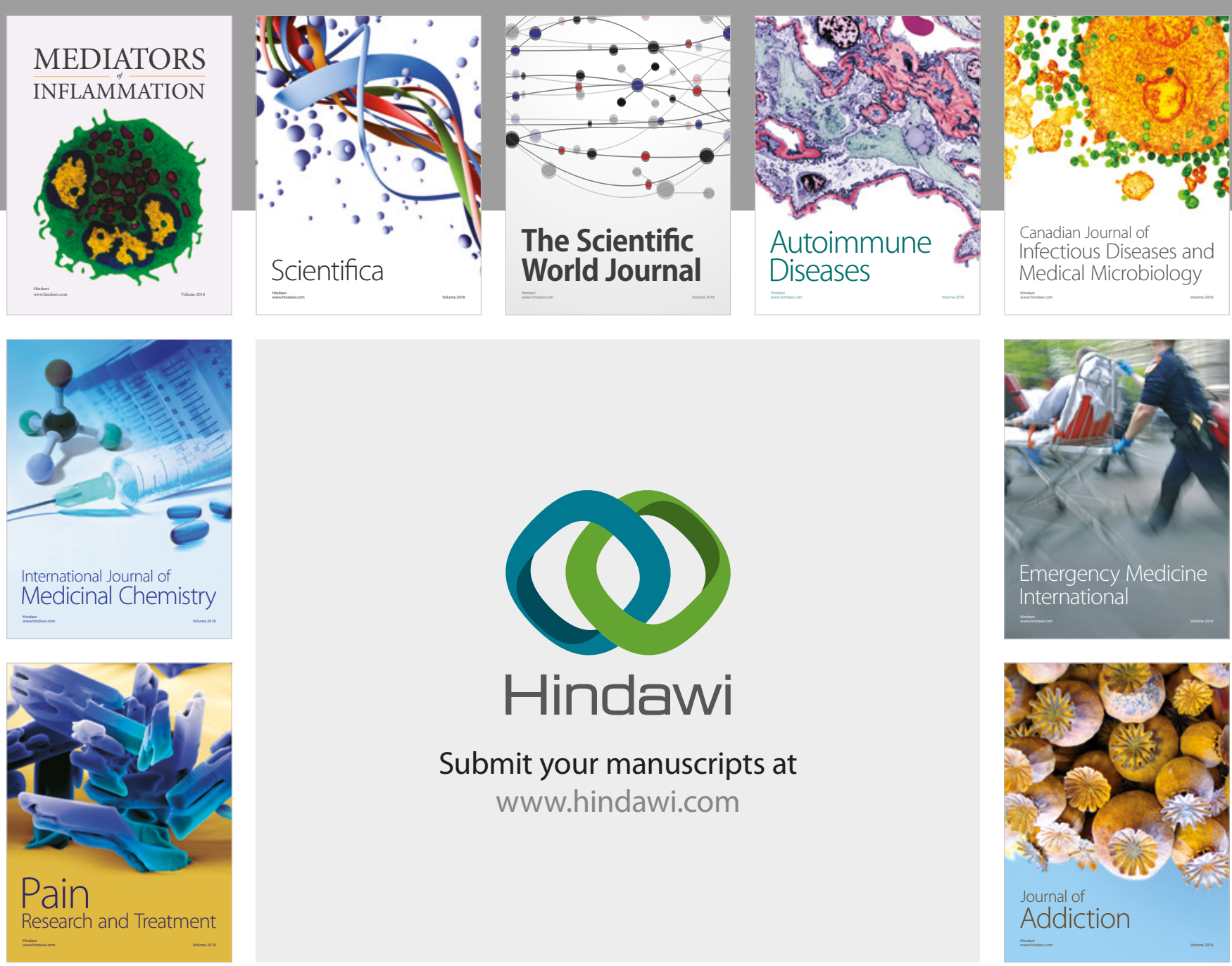

Canadian Journal of
Infectious Diseases and Medical Microbiology

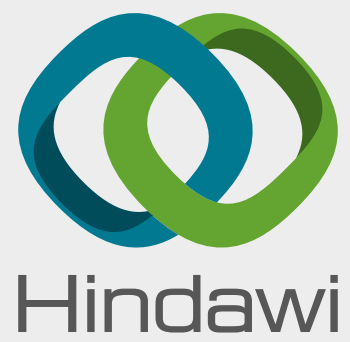

Submit your manuscripts at

www.hindawi.com
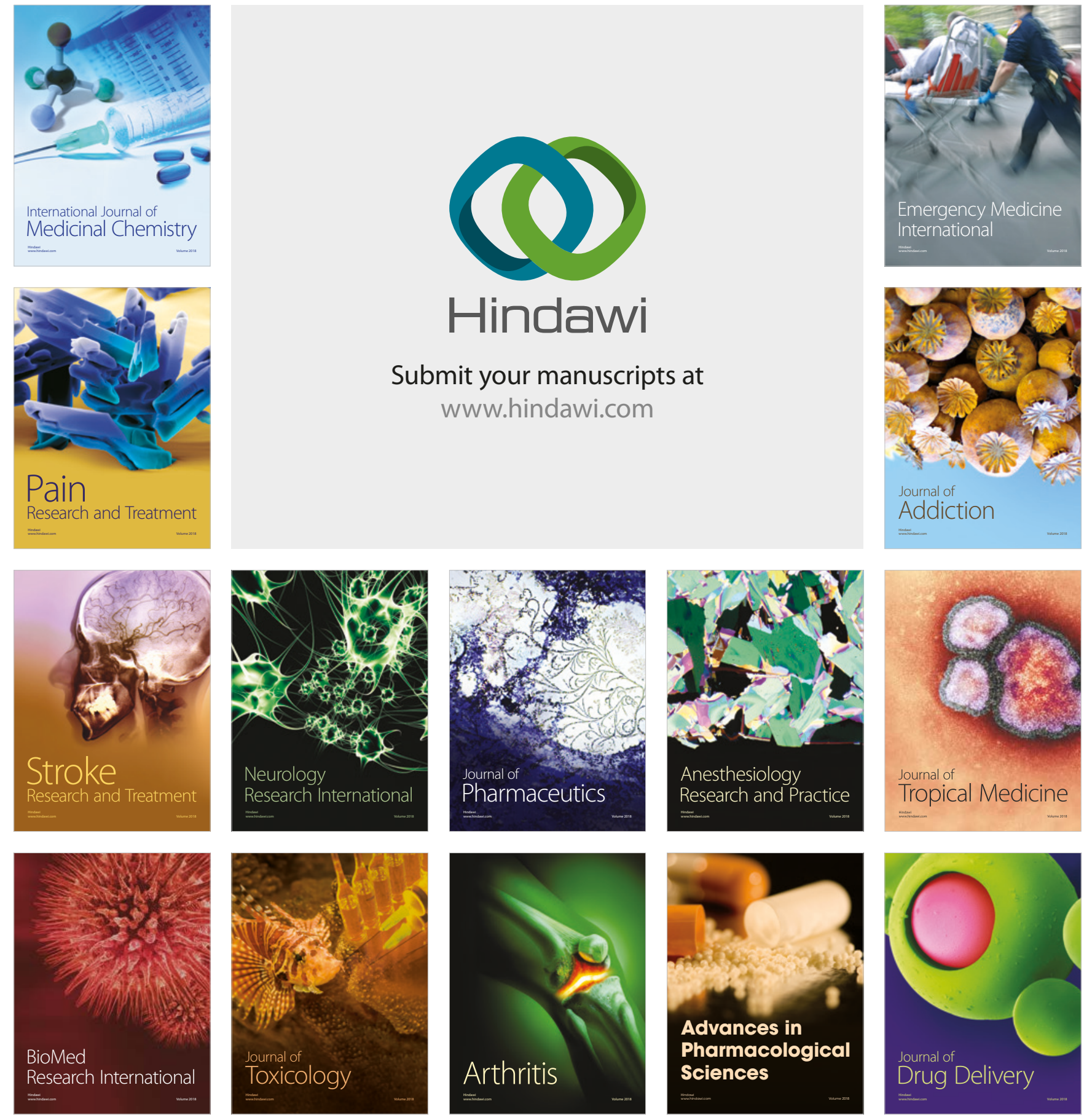